\title{
Cenas de microcefalia, de cuidado, de antropologia (Recife, setembro de 2017)
}

\author{
SORAYA FLEISCHER \\ Universidade de Brasília, Brasília, Distrito Federal, Brasil
}

DOI 10.11606/issn.2316-9133.v27i1p118-131

resumo Nesse artigo, trago cenas diretamente dos meus diários de campo (Saretta, 2015; Stevenson, 2017). Ao escolher fazer antropologia a partir, com e por cenas, viso valorizar o diário de campo, esse instrumento tão central na produção antropológica, mas pouco visto e conhecido; promover um deslocamento da onipresença e onipotência da tradução antropológica; pleitear a montagem como uma ferramenta estratégica nos processos de escrita etnográfica. Ao trazer cenas, a intenção é criar uma comunidade de cumplicidade e compromisso - entre protagonistas, etnógrafa e leitoras - para tentar se aproximar do que pode ser viver com um filho pequeno no epicentro da epidemia do vírus Zika, em uma democracia fragilizada, em um país do sul-econômico, nesses princípios do século XXI.

palavras-chave: vírus Zika; escrita etnográfica; diário de campo; Recife.

Scenes of microcephaly, care and anthropology (Recife, September 2017)

Abstract In this article, I bring scenes directly from my field diaries (Saretta, 2015; Stevenson, 2017). When choosing to do anthropology from, with and by scenes, the goal is to value the field diary, this central instrument in anthropological production, but little seen and known; to promote a displacement of the omnipresence and omnipotence of anthropological translation; to suggest composition as a strategic tool to ethnographic writing. In bringing scenes, the intention is to create a community of complicity and commitment - between protagonists, ethnographers and readers - and try to get closer to what can be to live with a young child in the epicenter of the Zika virus epidemic, in a fragile democracy, in a southern economy and in the beginning of the 21 st century.

Keywords Zika virus; ethnographic writing; field diary; Recife. 
Lembrando de bebês, unicórnios e diários de campo, feitos com fiapos de tempo, amor e imaginação.

Era uma tarde quente de setembro. Eu tinha chegado fazia alguns minutos numa clínica particular de terapias de reabilitação. Na sala de espera, encontrei Debora e seu filho Jonatas. Eu já os conhecia das outras visitas ao Recife e, a cada vez que retornava à cidade, ia marcando de encontrar as pessoas por onde estivessem circulando naquela semana. Essa mãe, uma jovem morena com quase 30 anos, segurava o filho, com pouco mais de dois anos. Esperavam pela sessão de fisioterapia numa antessala pequena e quadrada, mobiliada com um sofá de dois lugares, um bebedouro, alguns quadros pelas paredes e um vaso de planta. De repente, de uma das portas onde se lia "Administrativo", sai uma moça morena, de aparelho dentário, óculos e uniforme da clínica. Debora já a conhecia e passaram a conversar animadamente. O principal assunto foi a gravidez de outra fisioterapeuta da clínica, Mila. A moça do Administrativo reforçava que Mila não queria estar grávida. Debora já sabia dessa situação e concordava. Ouvi por alguns minutos e depois pedi que minha interlocutora contextualizasse melhor a história. Ela me passou Jonatas para que pudesse tirar-lhe os sapatos, já o preparando para a terapia que aconteceria em alguns minutos. Depois, começou a explicar que Mila estava a ponto de começar a fazer um curso específico na sua área da fisioterapia, que seria muito importante para a carreira dela. Era um curso sobre o therasuit, o colete especial que Jonatas começaria a usar em breve. (Eu inclusive participei com $\mathrm{R} \$ 150$ na vaquinha que Debora fez e me enviou pelo WhatsApp. O colete custava cerca de R $\$ 600$ no total). E agora, com a gravidez, Mila não poderia mais viajar e participar do curso e estava bem chateada com isso. A funcionária, ali de pé, explicava que Mila já tinha chorado muito, que não vinha aceitando a gravidez. “'Mas é um presente', eu falei para ela. É uma benção. A gente tem que aceitar, não tem outro jeito, não é não?", disse a funcionária. E continuou: “Acho que foi na troca do remédio. Ela estava fazendo o mesmo tratamento que eu. Mas a gineco dela trocou o remédio e acho que foi nesse momento que ela engravidou", complementou. "É isso mesmo. Aconteceu a mesma coisa comigo. Eu estava usando um tipo de anticoncepcional e fui trocar. Foi um único mês que eu não tomei e eu engravidei. Olha o meu presente aqui”, completou Debora, de modo irônico, passando a mão pelos cabelos encaracolados 
de Jonatas. As duas riram. Em seguida, a moça seguiu seu caminho e nós entramos para a sala de fisioterapia da criança.

\section{2}

Zélia tinha conseguido um emprego num bar. Pelo zap, ela me convidou para conhecer o local para, depois, seguirmos até sua casa. No final daquela tarde de sábado, Zélia estava sentada sobre as cadeiras de plástico, já todas empilhadas dentro do recinto. Ficamos ali conversando por meia hora, era o tempo que faltava para acabar seu expediente. $\mathrm{O}$ patrão, mesmo sem clientes, não a dispensou mais cedo. Ela tampouco parecia ansiosa para ir embora. Comentei do seu novo cabelo. Dessa vez, estava bem curto e com mechas loiras. "Deu uma louca lá na madrugada”, disse rindo. Óculos de armação enorme, um boné, argolas pretas nas orelhas e um colar estilo choker escrito "I love you". Depois de falarmos de cortes de cabelos, Zélia comentou sobre o ex-marido, pai de suas duas filhas mais novas. A primogênita era filha de um relacionamento anterior. "Faz uns meses, ele pegou a do meio para mostrar que sabia cuidar de criança”. Ele ficou com a menina por vários meses e Zélia exigindo que a devolvesse. A mulher atual do rapaz lhe telefonou, disse que iria devolver a criança porque estava muito doente. Deixou a menina na casa da irmã do rapaz, ex-cunhada de Zélia. Segundo Zélia, a própria companheira do cara preferiu devolver a criança e não mais ser cúmplice dos maus tratos. A filha voltou desidratada, com febre, com o ouvido sangrando, com a garganta estourada saindo pus. Zélia teve que correr com ela para o hospital, "Eu bati o olho na minha filha e vi que estava doente, porque a gente sabe dos filhos da gente só de olhar, né? Ela não estava com nenhum sorriso, estava magrinha de tudo. Porque se mexe com as minhas filhas, eu viro bicho”. Ela usou essa última frase várias vezes durante a noite. "Ele não sabe e não quer ser um pai de verdade para elas. Eu já entrei na justiça contra ele, mas eles não encontram o homem, não encontram em endereço nenhum. Se eu encontrar com ele na rua, eu mato. Ah, eu mato esse homem. Com uma semana que eu descansei da minha caçula, ele me agrediu, você acredita? Eu, com pontos na barriga, sem poder levantar direito e ele me agrediu. Como pode ser uma pessoa assim? Imagina agora se eu não faço coisa muito pior, depois de ele ter me devolvido minha filha desse jeito?”. Quando a caçula, que tem microcefalia, ficou internada da última vez, a médica prescreveu quatro tipos de remédio. "E ela ia trocar o Keppra pelo Sabril. Mas eu pedi que não, que ela aumentasse o Keppra em vez de tirar o 
Sabril porque o Keppra eu pego na farmácia pública e o Sabril eu tenho que comprar”. Zélia voltou para casa com todos os remédios, aqueles que pegou na farmácia e os que precisou comprar. Ela decidiu tirar uma fotografia: deitou a filha na cama e colocou todas as caixinhas de remédio enfileiradas ao lado da menina. Pelo telefone celular, mandou a imagem para o ex-marido, pedindo $\mathrm{R} \$ 100$ para ajudar a pagar pelos remédios. "Ele nunca nem respondeu. Ele não paga PA, ninguém da família dele ajuda as meninas, nem manda nada para as minhas filhas”. O pai da filha mais velha de Zélia tampouco paga a PA, mas a irmã desse rapaz manda algumas coisas de vez em quando. "Não sei se é ela que manda ou se é ele que manda por ela. Mas chega lá em casa”. Deu sua hora, pegamos o ônibus e fomos até sua casa.

\section{3}

Tarde quente lá fora e nós refugiadas dentro do ar condicionado da repartição da Farmácia do Estado, ali na Secretaria Municipal de Saúde do Recife. Eu tinha acabado de dar o leite ao Danilo pela sua sonda por gastrostomia. Sua mãe, a jovem Marta, estava no balcão, dando entrada numa papelada. De repente, ela volta até onde estávamos. Faltava um documento. Danilo tinha ficado satisfeito com o almoço, estava calminho e permaneceu na sua cadeira de rodas. Eu fui sentar-me ao lado de Marta, para lhe ajudar no balcão. A atendente era muito doce, muito paciente. Explicou que faltava o eletroencefalograma ou, se esse exame não pudesse ser realizado na criança, que fosse trazida uma declaração que atestasse essa impossibilidade. E acrescentou, solícita, "Ah, mais uma coisa. Veja só essa receita, ela vence agora no dia 28 de setembro. As receitas só duram um mês, ela é de 28 de agosto. Então, ou você vem antes disso ou você precisa ir na médica e renovar a receita, ok?”. Era uma dica muito importante para que Marta não perdesse a viagem, levando apenas o eletro. Marta tinha ficado um pouco chateada com a informação sobre a documentação incompleta. Ela explicou, "A médica me disse assim: 'Se não der certo com esses documentos, você volta aqui e a gente providencia outros'. Agora, me diz, por que já não me deu todos os documentos necessários, né? Por que me fazer ter que voltar lá de novo? E ainda preciso descobrir quando essa médica atende lá”. Eu interrompo, "Não é possível só ligar para saber?”. "Mas quando! Quando é que o telefone de lá atende? O telefone não atende. Vou ter que ir lá para descobrir quando ela está lá atendendo. Aí, eu volto no dia em que ela estiver lá. Ela vai ter que fazer essa declaração e 
também atualizar a receita. Aí, só aí eu vou poder voltar aqui”. Ela fica em silêncio, pensativa. De repente, emenda: "Bem que o pai do Danilo poderia resolver tudo isso, né não?”. Eu comentei que tinha pensado justamente nisso porque é um tipo de tarefa que não precisa trazer a criança junto, como nas terapias, por exemplo. "E ele trabalha bem aqui [no bairro da] Madalena, bem mais perto. Eu fiquei sabendo que ele está trabalhando. Mas ele não fala de jeito nenhum onde é o serviço dele". Por que, eu quis saber. "Porque ele sabe que se eu souber o local, eu posso pegar o nome da empresa e entrar com o processo para ele pagar a pensão. Aí, a empresa, se ela for citada, ela passa a descontar a PA direto do contracheque dele, entende? E ele não quer isso”. Eu tinha entendido que seu ex-marido não estava pagando a pensão alimentícia de Danilo. Mas não era exatamente isso: "Não, agora ele paga direitinho todo mês. Mas ele me deve o ano passado, não pagou o ano passado. Tem uma dívida comigo, entende? Eu falei para ele, que se ele conseguir pagar um plano de saúde para Danilo, eu perdoo a dívida dele. Mas ele não fez isso. Então, me deve ainda". "Mas eu acho que ele não vai vir aqui fazer essa coisa do medicamento. Vai nada. É difícil ali, visse”. Como seria para o pai da criança vir fazer os trâmites, Marta perguntou à atendente. Além dos documentos pessoais da mãe, ele deveria anexar também os seus ( $\mathrm{RG}, \mathrm{CPF}$, comprovante de residência etc.). Mas a recíproca não procedia, quer dizer, se fosse Marta a realizar a burocracia na Farmácia do Estado, ela não precisaria trazer os documentos dele. Era um sistema que parecia onerar as mulheres. Notei duas placas afixadas na parede, cada uma se referia a um conjunto das cadeiras de espera: "Espera por inicial” e "Espera por renovação". Quando a supervisora do lugar passou por nós e fez festinha nos cabelos castanhos de Danilo, eu aproveitei para entender o conteúdo daquelas duas placas. O primeiro caso era para as pessoas que, como Marta, estavam iniciando o processo de concessão gratuita dos remédios de alto-custo. O segundo caso era para quem estava renovando-a. Nesse caso, ela me explicou: "A cada mês, a pessoa vem pegar seus remédios. A cada três meses, é preciso trazer uma receita atualizada e todos os documentos novamente. Essa é a renovação”. Eu estava chocada! Pacientes, ou geralmente as mulheres cuidadoras, tinham que vir até o centro da cidade todo mês, trazer toda a documentação novamente e torcer para terem acesso aos medicamentos. Parecia que o Estado estava presumindo (ou apostando?) que os doentes crônicos não durariam tanto e, por isso, exigia-se a renovação em intervalos tão curtos. 
Sinara era avó de Kennedy, de quase três anos. Ela cuidava do neto durante o dia, enquanto a filha e o genro trabalhavam. De noite, Kennedy voltava para casa. Sinara conhecia toda a rotina de alimentação, sono, humor e sintomas da síndrome congênita do vírus Zika de seu neto. Dessa vez, nós nos encontramos na clínica de reabilitação no bairro vizinho, para onde ela levava o neto três vezes por semana. Estávamos sentadas sobre o tatame, enquanto a criança tirava uma pequena soneca ali do nosso lado, entre uma sessão e outra de exercícios. Ela me contou do último evento hospitalar que a família tinha vivenciado, algumas semanas antes de eu chegar à cidade. "O problema é que ele deu entrada no Hospital da Restauração com crise convulsiva. Chegamos e ele logo foi internado. Com alguns dias, ele estava diagnosticado com pneumonia, minha gente! Como pode uma coisa dessas? Entra com uma coisa e desenvolve outra lá dentro? Como pode? Ninguém explicava nada para a gente. Nenhum médico explicava porque ele estava com outro problema agora. Eu não aguentei, tinha que descobrir o que estava acontecendo. Fui com minha irmã. Você conhece ela, não dá ponto sem nó. Eu preciso muito da minha irmã, da força dela. Ela tinha saído do trabalho, estava toda arrumada, com salto e tudo. Parecia que ela era minha advogada. A gente chegou lá e já foi pedindo para falar com o gerente. E ninguém deixava subir, mas a gente foi tentando assim mesmo, subindo as escadas e batendo nas portas. A gente queria saber o que estava acontecendo com o Kennedy. Até que chegamos no gerente e contamos toda a história para ele. Eu falei bem assim para ele, 'Olha aqui, olha aqui: não é porque ele tem microcefalia que queremos que ele morra, não, viu?’. Falei mesmo assim. Eles têm que entender que, mesmo tendo micro, ele é cuidadinho demais pela gente, a gente faz tudo por ele. A minha irmã foi e falou assim também, 'Os pais são muito novinhos. Se vocês não querem contar a verdade para eles, tudo bem. Mas pode contar para nós, visse. Pode contar'. A gente falou isso tudo. E deu certo, eles mandaram um médico que, na hora, desceu com a gente e foi ver o prontuário do Kennedy. Leu tudinho, do começo ao final, tudo que tinha sido escrito ali. E explicou para gente com muita calma, com todos os detalhes. Ele tinha pego uma bactéria de pneumonia ali dentro do hospital. E a equipe vinha tentando dar vários antibióticos para ele. Tinham tentado um, depois tentado outro, mas nada vinha funcionando. Ele já estava lá fazia 15 dias e não tinham acertado o antibiótico ainda. Era isso que estava difícil, entendeu? O problema é que ele entrou com uma coisa e lá dentro pegou outra. Isso foi muito difícil para ele, 
tadinho. Depois que a gente foi parar lá na administração do hospital, com cinco dias, ele desceu pro quarto. Com cinco dias, ele deixou a UTI. E depois teve alta. Imagina se a gente não tivesse arengado, o que teria acontecido? Eu acho que ele tinha morrido mesmo, morrido lá dentro sem o hospital fazer as coisas direito".

\section{5}

Melissa era fisioterapeuta numa clínica de bairro popular. Ela me permitia estar presente, conversar com ela e as demais mulheres enquanto os exercícios iam sendo realizados. Por vezes, ela me pedia ajuda para segurar uma criança, varrer a ampla sala onde trabalhava antes de todo mundo chegar, chamar a próxima mãe a ser atendida. Certa manhã, ela me contou que, por sete anos, cuidou de sua filha "rara". A criança nasceu com uma síndrome raríssima, à época o único caso no país. Dali a alguns dias, completariam nove anos de sua morte e Melissa vinha pensando nisso. "Você sabe, Soraya, foi erro médico mesmo. O médico quis colocar uma válvula na cabeça dela, quando apareceu uma bola assim, que era típica da síndrome. Ele colocou cinco válvulas nela. A primeira custou $\mathrm{R} \$ 1.000$; a segunda, $\mathrm{R} \$ 3.000$; a terceira, $\mathrm{R} \$ 8.000$ e por aí foi”. "Nossa, super caro!", eu comentei, "Como foi possível pagar por tudo isso?". "Ah, o plano pagou as três primeiras", dando a entender que ela teve que se virar para pagar as duas últimas cirurgias. Melissa continuou a lembrar: "Mas o problema é que isso tudo foi o médico brincando de experimentar. Ele era um médico que não acreditava em deus, era ateu mesmo. Quem me contou isso foi uma pediatra que trabalhava com ele na sala de cirurgia. Ela disse que não queria mais trabalhar com ele, não queria entrar mais com ele para o bloco cirúrgico por conta disso. Numa ocasião, ela o ouviu falar, olhando para uma criança com deficiência que estava sendo operada, 'Deus faz a merda e eu tenho que ficar consertando aqui'. Ele falou isso, em plena sala de cirurgia! Veja só isso!". E ela continuou, "Porque muitos deles, antes de operaram, rezam, né? Fazem um círculo para fazerem uma oração e tudo. E ele não tinha nada disso. Essa pediatra que eu conheci se recusou a trabalhar com ele. Como operar sem acreditar em deus, minha gente? Sem esperar a luz divina para ajudar ali na hora? Não dá. Eu não boto meu filho na mão de médico que não acredita”. E ela lamentava, esse tinha sido o médico que operara sua filha todas às vezes, na colocação das cinco válvulas. 


\section{6}

Naquele sábado de sol, fui até um bairro da periferia recifense. Peguei um ônibus, um metrô e caminhei umas quatro quadras até a casa de Marta. Quando cheguei, ela estava começando o almoço. Fiquei papeando com ela na cozinha, depois fui brincar com seus dois filhos mais velhos, enquanto o caçula, Danilo, tirava uma soneca. Quando ele acordou, peguei-o no colo e ficamos todos ali na sala, enquanto a comida apurava. De repente, ouvimos palmas. "Ah, é meu tio”, explicou Marta. Ele tinha vindo buscar a mesa da cozinha com duas cadeiras. "É dele, sabe, estava aqui emprestada por um tempo". Ela vai lá fora abrir o portão. O senhor, forte e sem camisa, retirou a chinela, entrou na casa. Ele me reconhece, me cumprimenta com um aperto de mão, faz um carinho no cabelo de Danilo e vai buscar as cadeiras. Foi ele quem ajudou Marta, durante a última quinzena em que eu estivera na cidade, quando ela saiu da casa da mãe e se mudou para uma casa nesse outro canto da cidade. Eu tinha ajudado naquela mudança e por isso já o conhecia. Um segundo senhor, que tinha vindo ajudar a carregar os móveis, ficou ali no portão. Marta depois explicou ser um "primo do primo do primo, mas que não conhece direito, não". Ele olha para dentro da casa, vê Danilo em meus braços e pergunta à Marta, "Cadê o doentinho?". Ela não deixa um segundo passar e dispara: "Ele não é doentinho, não. Ele tem nome, visse?”. Eu a ajudei, “Aqui está o Danilo, o nome dele é Danilo”. O senhor cumprimentou a criança de longe. Só depois, ele entrou, pegou o tampo de mármore da mesa. Os dois homens saem carregando o peso. Quando todos partem, Marta se vira pra mim, com sangue no olho, como se diz por ali, e vocifera quase gritando, "Eu me arreto com esse homem toda vez! Toda vez é isso, fica chamando Danilo de 'doentinho'. Que ódio isso, afe!”. Ela fecha o portão com força e entramos. Ponho Danilo na sua cadeirinha. Eu me sento para escrever um pouco no meu caderno de campo, Marta vai até a cozinha. As duas crianças mais velhas vêm se sentar perto de mim. Dou o caderno para eles desenharem. Nisso, o marido de Marta nos chama aos berros. Ela vai até o portão ver o que está acontecendo dessa vez e me chama exultante, "Vem, Soraya, vem, corre! Vem ver!”. Chego lá, acompanhada dos dois meninos curiosos. Um vizinho está segurando uma cobra verde em um longo pedaço de pau. Várias pessoas chegavam perto para ver melhor. Era a atração do momento. Segundo minha anfitriã, uma casa ali para baixo, perto de onde compramos o refrigerante do almoço, dava para uma área de mato. A cobra entrou pelo telhado e estava indo em direção à gaiola do passarinho. "Estava com fome a bicha”, diz um. Era linda, de 
um verde bandeira viçoso. Estávamos todos fascinados. A todo tempo, ela serpenteava pelo toco de madeira e tentava dar o bote no homem que o segurava. Um dos filhos de Marta ficou repetindo, "Olha, olha! Ela tem uma boca, ela vai comer você. Ela tem uma boca enorme, ela vai comer você”. Ela tem uma boca, ela é braba que só.

\section{7}

A sessão de fonoaudiologia de Cristiano tinha terminado. Rose me passou a criança para que eu ajudasse a vesti-lo. Nós nos despedimos da terapeuta. Ela deu um último aviso, "Como a Soraya não viu ainda a hidroterapia do Cris, mostre para ela onde é a piscina e como funciona, visse?”. Rose achou uma boa ideia. Descemos para o primeiro andar. Dobramos à esquerda e eu vi uma porta de vidro, que separava a recepção de outro bloco onde ficavam as piscinas, vestiários e banheiros. Ali naquele ponto, estava outra mãe, acompanhando seu filho adolescente. Eles estavam parados na porta de vidro, o rapazinho olhava para baixo, onde havia uma rampa que levava para um nível um pouco mais baixo do piso. "Vai, meu filho, você consegue ir ao banheiro sozinho", a mãe incentivava. Logo depois da rampa, havia a porta do banheiro masculino. Ela continuava a lhe insuflar com palavras de apoio. Rose passou ao seu lado e desceu a rampa. Eu fui mais devagar, porque estava com Cristiano no colo. Preferi esperar o ritmo do rapazinho, que caminhava com dificuldade, uma perna depois da outra, apoiando-se pelas paredes. Nós três, mães e mulheres adultas, prestávamos atenção em seus passos. Ele lentamente passou pela porta de vidro, com cuidado desceu a rampa e, ao final, ali do lado de Rose, ele desabou no chão. Seus pés tropeçaram um no outro, ele perdeu o equilíbrio e caiu. Eu estava segurando Cristiano no colo e não tive rapidez para reagir, mas quando me locomovi mais rapidamente para frente, a mãe colocou a mão no meu ombro, "Não precisa se preocupar, minha querida. Ele é muito pesado, você não vai dar conta de segurá-lo”. E ao filho, ela disse, "Vai, meu amor, você dá conta de levantar. Vai, tenta se levantar". Ela passou à minha frente, mas sem correria ou pressa, e foi oferecer a mão ao filho. Ela não tinha ficado preocupada com a queda e parecia aproveitar o momento para ensinar autonomia ao filho. Cair talvez fosse comum, talvez a mãe já tivesse visto isso acontecer muitas vezes. Rose viu a cena de perto, mas nada fez nem nada disse. Fiquei pensando se a cena lhe projetara para o futuro, se ela se imaginou acompanhando Cristiano mais velho, ali naquela mesma clínica de reabilitação. Eu não lhe dirigi minhas hipóteses. Nós nos entreolhamos e ela se 
virou e seguiu até a piscina. Segui atrás com Cris nos braços, para nele colocar o calção de banho.

\section{8}

Naquela tarde, nós fomos resolver coisas burocráticas das crianças ali no centro da cidade. Éramos cinco, eu, Marta, Rose e seus filhos, respectivamente, Danilo e Cristiano. Começou a chover torrencialmente, como é frequente no Recife. E decidimos nos abrigar num supermercado ali pertinho. A chuva insistiu e, como não havíamos almoçado, sugeri que lanchássemos por ali. Na padaria, pedimos uns salgados e sentamos para comer. Marta dava pedacinhos minúsculos da coxinha com catupiry para Danilo experimentar. Ele vinha usando uma sonda gástrica fazia muitos meses, mas ela gostava de continuar estimulando sua boca, para "ele não esquecer como é comer". Depois, Rose deu uma colherinha de mousse de limão ao Cris, que rapidamente fez uma careta de repulsa. Todas rimos, "Ele não gosta mesmo de açúcar, gente! Sorte sua, meu filho, que não é viciado como eu”. Nisso, uma moça com uma criança no colo se aproximou de onde estávamos sentadas. A moça passou por nós, comprou algo no balcão e já foi se dirigindo ao caixa. Rose disparou com desinibição, “Oi, tudo joia?”. A moça retribuiu o cumprimento de modo muito simpático, mas não parou para conversar conosco. Quando ela já tinha se afastado, Rose se virou para Marta, “Tá vendo, a gente nem conhece, mas já se reconhece. É mãe de micro, você viu? Eu não conheço ela e tu?". Marta tampouco a conhecia, mas completou, "Mas a gente se percebe logo pela micro, já vê que é outra mãe de micro, né?”. Elas riram. "A gente conhece a outra não pela pessoa, mas pela patologia, você vê?”, dispara Rose, por fim. Terminamos de comer, pagamos a conta e seguimos até a Secretaria Municipal de Saúde, nosso destino de labuta daquela tarde.

$$
* * *
$$

Nesse estilo narrativo, trago trechos, relatos - ou cenas, como prefiro caracterizálas - diretamente dos meus diários de campo, como outros antropólogos também têm tentado fazer em seus textos (Saretta, 2015; Stevenson, 2017). Há alguma edição para resguardar anonimato, para as frases fazerem sentido quando retiradas de um contexto mais amplo, para que o drama central da situação fique um pouco mais evidenciado. Ao 
escolher fazer antropologia deliberadamente a partir, com e por cenas, viso alguns objetivos, como comento a seguir.

Desde 2016, eu e equipes compostas por pesquisadoras de graduação, mestrado e doutorado temos visitado o Recife/PE. A cada semestre, passamos uma quinzena (re)encontrando, acompanhando e conversando um mesmo conjunto de mulheres que tiveram filhos com a síndrome congênita do vírus Zika entre 2015 e 2016. Em duplas ou trios fazemos atividades de pesquisa de campo durante o dia, individualmente escrevemos diários de campo durante o período da noite. Depois, circulamos versões editadas desses diários entre nós. Circular esse material dentro da equipe funciona como um importante passo metodológico e pedagógico e permite criar um corpus empírico que pode ser (re)utilizado por essa e também equipes futuras. As cenas da montagem que apresento nesse artigo vêm, especificamente, do período mais recente de pesquisa de campo, realizada em setembro de 2017, quando dessa vez, excepcionalmente, viajei sozinha (em razão dos profundos cortes orçamentários que assolam a ciência brasileira nos últimos anos).

Apresentar cenas é uma forma de também valorizar o diário de campo, esse instrumento tão central na produção antropológica, mas que pouco se vê e se conhece, que tão raramente deixa o escritório ou o computador da etnógrafa. Quero valorizar o esforço que é produzi-lo, depois de horas intensas de circulação por uma cidade e de tentativa de compreensão do que é descrito pelas pessoas com quem convivo no Recife. O esforço no sentido de, embora cansada do dia de trabalho e intensamente afetada pelo que vi e aprendi nesse dia, registrar o que de mais impactante me atingiu a memória, a emoção e o diálogo com as temporadas de campo anteriores. Esse registro pretende imprimir o alvoroço do encontro, a intensidade do que foi dito, observado e sentido. Considerar, em nossos textos que vão para a publicação, os diários de campo de um modo direto é honrar do começo ao fim esse material produzido por nós. Há a vontade de não deixar o diário de campo escondido por trás de abstrações conceituais e generalizações despessoalizantes, como mais comumente vejo nos textos antropológicos, inclusive nos meus. Há um intuito didático aqui também, já que pouco é falado, ensinado ou compartilhado sobre esse tipo de produção. Revelar o diário de campo permite, por um lado, que ele seja reinstituído de autoridade, retendo o brilho que originalmente ganhou quando foi produzido. E, por outro lado, deixa aparente a forma como cada pesquisadora trabalha; no caso, como eu faço 
pesquisa, como eu abordo, converso, instigo e depois relato sobre meus encontros e minha convivência em campo. Estou afirmando que o diário de campo é muito mais do um dado bruto (supostamente esperando a lapidação antropológica, sendo lá o que isso queira dizer); ele é uma ferramenta muito mais polivalente do que apenas um "material de pesquisa”. É uma das formas de escrita mais comuns, exaustivas e presentes na nossa lida profissional, mas paradoxalmente desvalorizado em nossos textos finais. E, por tudo isso, pode se transformar um material também docente e útil para a formação de quadros na antropologia.

Os textos da presente pesquisa têm sido escritos em formatos mais canônicos, para congressos, revistas e livros, mas nem sempre sinto que esses textos são capazes de captar a intensidade do que eu presencio ao acompanhar essas "mães de micro" no Recife, como elas decidiram se chamar. Os textos canônicos servem a um tipo de comunicação acadêmica e cumprem os ritos exigidos por essa comunidade. Também temos tentado escrever textos menores e mais acessíveis para um público mais amplo, não necessariamente acadêmico. É um intuito claro de popularização da ciência, de ocupação da mídia com antropologia e de manutenção do tema da epidemia na pauta pública. Essas "microhistórias", como chamamos, já que se referem exclusivamente às histórias que ouvimos no Recife, podem ser encontradas no blog homônimo que criamos. ${ }^{1}$

Ainda assim, sempre que eu retomo meus diários de campo, esbarro com trechos, com cenas particularmente eloquentes e impactantes, que não encontram espaços adequados para serem apresentados. No formato mais convencional, sinto que minha voz, como aquela que supostamente deveria reunir, editar e analisar o que foi vivido e registrado durante o trabalho de campo, torna-se preponderante demais. O fato de já ter feito a pesquisa e ter escrito sobre ela no calor da hora já deixa minha marca de percepção e autoria com nitidez demasiada. Aqui, ao apresentar um conjunto de cenas, quero promover um pouco de deslocamento da onipresença e onipotência com a qual nós nos investimos quando tomamos a caneta, quando assumimos o teclado. Por isso, propositalmente, esse pequeno comentário foi acrescentado ao final desse artigo, depois que as cenas tivessem sido apresentadas, depois que elas pudessem falar um pouco por si mesmas e sem mais uma interrupção irritante de minhas explicações. Por isso também esse

\footnotetext{
${ }^{1}$ https://microhistorias.wixsite.com/microhistorias
} 
comentário não pretende (tentar) explicar as cenas em si, mas apenas dizer uma ou outra palavra sobre a escolha por fazer antropologia através de cenas.

Quero retirar algumas das camadas de tradução que tradicionalmente me são exigidas nos textos acadêmicos. Embora eu tenha escrito esses diários de campo, considerando os filtros (in)conscientes de minha trajetória profissional sobre a minha forma de ver e registrar o mundo, quero acreditar que o diário de campo é um tipo de texto que ainda guarda alguma voz de nossas interlocutoras. Mas também quero "priorizar relatos de uma experiência etnográfica (...) de modo que as preocupações éticas dos limites de uma relação com a diferença e os próprios limites da etnografia possam ser problematizados" (Saretta, 2014, p.59). Mas se tento me retirar um pouco do papel de editar ou refratar o que me foi dito (ou, melhor, o que eu julgo ter ouvido em campo), reconheço que o avizinhamento das cenas (um corte e cola evidente) ainda é outra forma de editar e refratar. Aqui, desejo explicitar e, mais do que isso, pleitear a montagem como uma das ferramentas mais usuais, estratégicas e pouco discutidas nos nossos processos de escrita. Sou inspirada por Lise Stevenson: "Como na montagem cinematográfica, eu queria que a justaposição das imagens sugerisse uma 'terceira coisa' - algo que não estivesse dentro de nenhuma das imagens. O texto se pensaria através das imagens e não em uma sessão de discussão convencional" (2017, p.220, tradução livre).

Aposto também nesse poder das imagens. A ideia de "cena" tem inspiração no enquadramento teatral da realidade, que reúne e compõe personagens, figurinos, cenários, objetos, falas, enredos, atmosferas, ritmos. Mas essas cenas na capital pernambucana, diferente de uma peça de teatro formal, são muito menos ensaiadas e muito mais improvisadas (Spolin, 1986), mesmo com a eventual ajuda de "props", de adereços simbólicos, de encontros inesperados apresentados pela cidade, de perguntas da antropóloga etc. Investir em cenas, com diferentes interlocutoras como protagonistas, em diferentes lugares do Recife, é fazer uma escolha de edição que promova muito mais um pot-pourri - termo com o sentido que identifico mais nas práticas de floricultura do que nas da música. Um compósito, uma justaposição sem conexões aparentes, mas com muitas possibilidades de aproximações e diálogos, uma vez que se permita ler de perto. Histórias e cenas vividas por diferentes "mães de micro", mas que revelam a diversidade de situações cotidianas dilemáticas e complexas que essas mulheres precisam enfrentar. Embora eu não inclua aqui imagens propriamente ditas, como fotografias ou stills, há um flerte com os 
efeitos da imaginação de quem conta, de quem escreve e de quem lê, produzindo, em algum sentido, uma antropologia visual também.

Assim, quero apostar no vigor evocativo das imagens que podem ser (re)criadas a partir das cenas que surgem com a descrição etnográfica. Imagens de situações e lugares bastante concretos que podem chegar ao público e ajudá-lo a se transportar, de modo empático, criativo e imaginativo, ao Recife de setembro de 2017. Ao trazer cenas como essas, a intenção é criar uma comunidade de cumplicidade e compromisso - entre protagonistas, etnógrafa e leitoras - para tentar se aproximar do que pode ser viver com seu filho pequeno no epicentro de uma epidemia, em uma democracia fragilizada, em um país do sul-econômico, nesses princípios do século XXI.

\section{Referências Bibliográficas}

SARETTA, Mário. "A verdade está aqui com a gente, quem é capaz de entender? Uma etnografia com participantes de uma Oficina de criatividade em um hospital psiquiátrico”. In FERREIRA, Jaqueline e FLEISCHER, Soraya (orgs.). Etnografias em serviços de saúde. Rio de Janeiro: Garamond, 2014, pp. 57-80.

SPOLIN, Viola. Theater games for the classroom: a teacher's handbook. Evanston: Northwestern University Press, 1986.

STEVENSON, Lise. “A proper message”. In PANDIAN, Anand e MCLEAN, Stuart. (orgs.). Crumpled paper boat: experiments in ethnographic writing. Durham: Duke University Press, 2017, pp. 209-221.

Autora Soraya Resende Fleischer

Graduada em Ciências Sociais e mestra em Antropologia Social, ambos pela Universidade de Brasília. Também é doutora em Antropologia Social pelo PPGAs da Universidade Federal do Rio Grande do Sul e estágio pós-doutoral em Antropologia pela John Hopkins University. Atua como professora no Departamento de Antropologia da Universidade de Brasília

Recebido em: 19/02/2018 Aceito para publicação em: 28/09/2018 